\title{
Easy Is Not Always Good - The Fragmented System for Adjudication of Unitary Trade Marks and Designs
}

\author{
Annette Kur
}

Accepted: 15 March 2021 / Published online: 3 May 2021

(C) The Author(s) 2021

\begin{abstract}
While the creation and still outstanding implementation of the Unified Patent Jurisdiction system continue to cause contentious debates among academics and practitioners, the system introduced in the early 1990s for adjudication of conflicts concerning unitary trade marks (and, later on, unitary design rights) had the charm of simplicity. Building on the national court systems instead of providing for a genuine EU judiciary, the scheme could easily be fitted into existing structures. On the other hand, the imperfect, limping character of the system creates issues inter alia concerning international jurisdiction and applicable law. Furthermore, attributing jurisdiction in infringement litigation to separate national court hierarchies may jeopardize the coherence of the system. While the prospects for reform may be dim insofar as the system in its entirety is concerned, the detrimental effects of fragmentation could be overcome at least to some extent by creating a unitary catalogue of sanctions.
\end{abstract}

Keywords EU trade mark law · EU design law · International jurisdiction · Applicable law $\cdot$ Sanctions for infringement

\section{Introduction}

During his long and successful career at the Max Planck Institute and as an eminent lawyer, Jochen Pagenberg has dealt with many issues in IP law that took him to the

\footnotetext{
A. Kur $(\bowtie)$

Prof. Dr. Dr. h.c.; Affiliated Research Fellow, Max Planck Institute for Innovation and Competition, Munich, Germany

e-mail: annette.kur@ip.mpg.de
} 
forefront of legal debates and developments. For instance, I remember him being active in the at that time relatively novel field of character merchandising, ${ }^{1}$ fighting inter alia against what he considered as serious disparagement of a unique cast of endearing personae inhabiting a small, unyielding village in ancient Gallia. ${ }^{2}$ Not being a character himself who is easily coaxed into complacency, Jochen in his later years became widely known as one of the critical observers of the back-and-forth steps taken towards the creation of a unitary patent system and judiciary. ${ }^{3}$ While those efforts finally took form in Regulations (EU) No $1257 / 2012^{4}$ and (EU) No 1260/2012, ${ }^{5}$ as well as in the Unified Patent Court Agreement (UPCA), the ultimate fate of that project still hangs in limbo after Brexit, ${ }^{6}$ and more legal challenges than we have seen so far $^{7}$ may be raised.

However, that is not my topic for this homage to my old friend Jochen. What I want to address in the following is the alternative model chosen by the makers of the unitary rights systems already existing at the EU level, that is, European Union trade marks (EUTMs) and Community designs (CDs). ${ }^{8}$ Unlike the unitary patent package, the ambitious plan of creating a common EU judiciary for adjudication of infringement and validity of EUTMs and CDs was never pursued. ${ }^{9}$ Instead, Member States were obliged to designate national courts to perform the task of Community/ EU trade mark and design courts that are competent to decide on claims concerning unitary rights (in the following: designated courts). The system has the charm of simplicity; it fits without problem into already existing structures. On the other hand, it fails to provide for a genuine EU judiciary. Although being "EU courts" by name, the courts deciding on infringement and counterclaims for invalidity are de

\footnotetext{
${ }^{1}$ See Pagenberg (1987) p. 457.

2 German Federal Supreme Court (Bundesgerichtshof-BGH), 11 March 1993, Case I ZR 263/91, (1994) GRUR 206, Alcolix.

${ }^{3}$ Pagenberg (2000) pp. 481-491; Pagenberg (2007) pp. 805-825; Pagenberg (2009) pp. 314-318; Pagenberg (2010) pp. 195-198; Pagenberg (2010) pp. 695-707; Pagenberg (2012) pp. 582-589.

${ }^{4}$ Regulation (EU) No 1257/2012 of the European Parliament and of the Council of 17 December 2012 implementing enhanced cooperation in the area of the creation of unitary patent protection, OJ L 361, 31 December 2012, pp. 1-8.

${ }^{5}$ Council Regulation (EU) No 1260/2012 of 17 December 2012 implementing enhanced cooperation in the area of the creation of unitary patent protection with regard to the applicable translation arrangements, OJ L 361, 31 December 2012, pp. 89-92.

${ }^{6}$ For differing opinions concerning the prospects of the patent package after Brexit, see Jaeger (2017) pp. 254-285; Gandía Sellens (2018) pp. 136-152; Tilmann (2020) pp. 847-851.

7 CJEU, 16 April 2013, Joined Cases C-274/11 and C-295/11, Spain and Italy v. Council; CJEU, 5 May 2015, Case C-146/13, Spain v. European Parliament and Council; and Case C-147/13, Spain v. Council; German Constitutional Court (Bundesverfassungsgericht - BverfG), 13 February 2020, Case 2 BvR $739 / 17$.

${ }^{8}$ That solution was commended as an alternative to the UPCA in a recent initiative by scholars and practitioners under the stewardship of Fernand de Visscher, Alain Strowel, Vincent de Cassiers and Luc Desaunettes; see Position paper on the Unified Patent Court (15 October 2020), Centre Droit Entreprise et Société (CRIDES), available at: https://uclouvain.be/fr/instituts-recherche/juri/crides/actualites/upcalternatives.html.

${ }^{9}$ Inspiration was, however, drawn from the patent system insofar as the provisions on international jurisdiction in the EUTMR and CDR were modelled on the (failed) Community Patent Convention (CPC) of 1975 .
} 
facto national fora acting and deciding within the context of separate judicial systems. The imperfect, limping character of the system is liable to create issues inter alia concerning international jurisdiction, applicable law, and coherence of the system. Some of those issues have been addressed and decided by the CJEU with one case still pending at this time.

In the following, an overview is first given on the regulation of international jurisdiction and applicable law with regard to unitary intellectual property (IP) rights in the relevant instruments of EU law (Sect. 2). Thereafter a presentation of the pertinent CJEU jurisprudence (Sect. 3.1) forms the background for suggesting a solution for the case currently pending (Sect. 3.2), with a brief conclusion pointing out the deficits of the system (Sect. 4).

\section{Legal Bases}

\subsection{General Rules on Jurisdiction and Applicable Law}

Rules governing judicial competence in litigation concerning civil and commercial matters are unified by Regulation (EU) No 2012/1215 (BR I a). ${ }^{10}$ As a general principle, all claims can be brought against a defendant before the courts of the Member State where he or she is domiciled (Art. 4 BR I a). In case of torts or delicts, jurisdiction is also vested in the courts at the place where the harmful event occurred (Art. 7(2) BR I a). Furthermore, claims can be brought before a different court from that of a defendant's place of domicile where he is one of a number of defendants joined in actions having the same factual and legal basis (Art. 8(1) BR I a). Finally, Art. 67 BR I a stipulates that the "application of provisions governing jurisdiction and the recognition and enforcement of judgments in specific matters which are contained in instruments of the Union" shall not be prejudiced. This means that specific rules set forth in Regulations No 2017/1001 on the European Union trade mark (EUTMR) ${ }^{11}$ and No 2002/6 on the Community design (CDR) ${ }^{12}$ take precedence, while the provisions in the BR I a operate by default. ${ }^{13}$

\footnotetext{
${ }^{10}$ Regulation (EU) No 1215/2012 of the European Parliament and of the Council of 12 December 2012 on jurisdiction and the recognition and enforcement of judgments in civil and commercial matters, OJ L 351, 20 December 2012, pp. 1-32. Prior to the enactment of the Regulation currently in force, jurisdiction was regulated by the Brussels Convention on recognition and enforcement of judgments in civil and commercial matters (1968) and, since 2001, Council Regulation (EC) No 44/2001 of 22 December 2000 on jurisdiction and the recognition and enforcement of judgments in civil and commercial matters, OJ L 12, 16 January 2001, pp. 1-23 (BR). The provisions of relevance in the context considered here did not change in their contents, but only in the numbering; for instance, what is now Art. 7(2) was Art. 5(3) in the previous texts.

11 Regulation (EU) No 2017/1001 of the European Parliament and of the Council of 14 June 2017 on the European Union trade mark, OJ L 154, 16 June 2017, pp. 1-99; originally enacted as Council Regulation (EC) No 40/94 of 20 December 1993 on the Community trade mark, OJ L 11, 14 January 1994, pp. 1-36; codified version published as Council Regulation (EC) No 207/2009 of 26 February 2009 on the Community trade mark, OJ L 78, 24 March 2009, pp. 1-42.

12 Council Regulation (EC) No 6/2002 of 12 December 2001 on Community designs, OJ L 3, 5 January 2002, pp. 1-24

13 See infra, Sect. 2.3.1.
} 
The law applicable in litigation concerning non-contractual obligations is determined by the rules enshrined in Regulation (EC) No 2007/864 (Rome II). ${ }^{14}$ For IP rights, Art. 8(1) Rome II stipulates that "[t]he law applicable to a non-contractual obligation arising from an infringement of an intellectual property right shall be the law of the country for which protection is claimed". That rule is complemented in Art. 8(2) Rome II by declaring that "[i]n the case of a non-contractual obligation arising from an infringement of a unitary Community intellectual property right, the law applicable shall, for any question that is not governed by the relevant Community instrument, be the law of the country in which the act of infringement was committed".

\subsection{Sanctions for Infringement}

In practice the reference in Art. 8(2) Rome II to "the law of the country where the act of infringement was committed" is of primary importance with regard to sanctions for infringement. Both the EUTMR and the CDR only contain a rudimentary set of sanctions. Article 122 EUTMR and Art. 98(1)(a) CDR set forth that courts must enjoin current or imminent infringements; furthermore, pursuant to Art. 89(1)(b) and (d) CDR, courts can order seizure of imitations of protected Community designs as well as of material and implements primarily serving to produce those items. Regarding further sanctions, courts must revert to the provisions in national law. The discrepancies potentially caused thereby are mitigated by the fact that Directive 2004/48/EC on Enforcement of Intellectual Property Rights (IPRED) ${ }^{15}$ has brought about a fair amount of harmonisation. This concerns inter alia damages, corrective measures, publication of judgments etc. However, this is far from claiming that because of the harmonisation achieved under IPRED, the issue of which law applies under Art. 8(2) Rome II to sanctions for infringement which are not regulated in the EUTMR or CDR has become largely moot. For instance, irrespective of harmonisation, the principles and methods for calculating damages diverge quite substantially in practice. Furthermore, IPRED does not regulate each and every aspect of claims for redress that the right-holder is entitled to. Thus, IPRED is silent with regard to the infringer's duty to render account of the gains derived from the infringement item, information that courts may need for computation of damages. ${ }^{16}$

\footnotetext{
${ }^{14}$ Regulation (EC) No 864/2007 of the European Parliament and of the Council of 11 July 2007 on the law applicable to non-contractual obligations (Rome II), OJ L 199, 31 July 2007, pp. 40-49.

15 Directive 2004/48/EC of the European Parliament and of the Council of 29 April 2004 on the enforcement of intellectual property rights, OJ L 157, 30 April 2004, pp. 45-86.

16 In the case currently pending before the CJEU (C-421/20, BMW v. Acacia, infra, Sect. 3.2) that aspect is of central importance.
} 


\subsection{Special Rules in the EUTMR and CDR}

\subsubsection{Jurisdiction}

Both the EUTMR and the CDR declare that international jurisdiction in matters concerning unitary rights in trade marks or designs is regulated by the BR I a and its predecessors, unless the specific rules set forth in the respective instruments provide otherwise (Art. 122 EUTMR; Art. 79 CDR). Jurisdiction is vested in the courts designated by the Member States as EUTM and/or CD courts which are exclusively competent to adjudicate on claims for infringement and counterclaims for invalidity (or revocation). Furthermore, if national law so permits, the designated courts are also exclusively competent regarding claims for threatened infringement and for declaration of non-infringement (Art. 124 EUTMR; Art. 81 CDR) ${ }^{17}$ Prerequisites and breadth of international jurisdiction of designated courts are regulated in Art. 125, 126 EUTMR and Art. 82, 83 CDR respectively. Competence lies with the courts in the Member State where the defendant is domiciled or, if he has no domicile in the EU, where he has a business establishment. If the defendant is neither domiciled nor has a business establishment in the EU, competence lies with the court in the Member State of the plaintiff's domicile or, failing that, a business establishment. If none of the parties is domiciled or has a business establishment in the EU, competence is vested in the courts of the Member State where the Office has its seat (Spain) (Art. 125(1)-(3) EUTMR; Art. 82(1)-(3) CDR). Furthermore, the parties can agree on the competent court, or enter an appearance (Art. 125(4) EUTMR; Art. 82(1)-(4) CDR). Jurisdiction of courts so determined is not subject to territorial restrictions (Art. 126(1) EUTMR; Art. 83(1) CDR).

An alternative head of jurisdiction is set forth in Art. 125(5) EUTMR and Art. 82(5) CDR: claims, except for declaration of non-infringement, can also be raised in the courts of the Member State "in which the act of infringement has been committed or threatened". In that case, the competence of the court seized is limited to "acts committed or threatened within the Member State where that court is situated" (Art. 126(2) EUTMR; Art. 83(2) CDR).

\subsubsection{Applicable Law}

As a matter of principle, the law to be applied in proceedings concerning EUTMs and CDs is primarily the law enshrined in the respective instruments (Art. 129(1) EUTMR; Art. 88(1) CDR). For matters not regulated therein, national law applies, which includes private international law (Art. 129(2) EUTMR; Art. 88(2) CDR). In addition to the sanctions expressly regulated in the CDR - injunctions and seizure of infringing goods and implements - Art. 89(1)(d) CDR specifies that competent courts may impose "other sanctions", which are provided by the law of the Member State in which the acts of infringement or threatened infringement are committed,

\footnotetext{
${ }^{17}$ In addition, Art. 124(c) EUTMR lists claims for compensation for use made before publication of a protected trade mark (Art. 11(2) EUTMR), and Art. 81(c) CDR lists claims for declaration of invalidity of an unregistered Community design.
} 
including its private international law. In the same vein, Art. 130(2) EUTMR points out that " $[\mathrm{t}]$ he EU trade mark court may also apply measures or orders available under the applicable law which it deems appropriate in the circumstances of the case". Both instruments further provide that designated courts must take measures in accordance with their national law to ensure that injunctions or other orders issued on the basis of the Regulations are complied with (Art. 130(1) second sentence EUTMR; Art. 89(2) CDR). Finally, for procedural matters, national procedural law (lex fori) applies (Art. 129(3) EUTMR; Art. 88(3) CDR).

\section{CJEU Jurisprudence}

\subsection{Cases Decided So Far}

In the following, CJEU decisions concerning international jurisdiction and applicable law in litigation involving unitary rights are presented in chronological order.

Adjudicative competence of courts in the Member State where an infringement occurs (Art. 125(5) EUTMR; Art. 82(5) CDR) was first addressed in Coty Germany v. First Note. ${ }^{18}$ The defendant, a Belgian company, had sold products infringing the plaintiff's EUTM to a German company that imported and sold the products in Germany. The defendant disputed jurisdiction of the German courts where the litigation had been brought against him. The question was thus referred to the CJEU whether German courts were competent to decide on the defendant's contribution to the infringement that took place in Germany. The CJEU referred to established jurisprudence under Art. 7(2) BR I a (then: Art. 5(3) BR) according to which jurisdiction in matters of torts and delicts is vested in the courts at the place where damage is caused as well as at the place where the tort produces its effects. ${ }^{19}$ As the infringement to which the defendant had contributed produced its effects in Germany, it was found that jurisdiction of German courts exists insofar as jurisdiction is determined on the basis of Art. 7(2) BR I a. In the actual case this concerned claims based on national unfair competition law. ${ }^{20}$ Concerning claims for infringement of the EUTM, however, the provisions in the EUTMR take precedence, meaning that jurisdiction was determined by Art. 125(5) EUTMR (then: Art. 93(5) CTMR) in lieu of Art. 7(2) BR I a. As Art. 125(5) EUTMR refers to the courts in the State where the "act of infringement" is committed or threatened, the CJEU concluded that bringing proceedings in Germany was excluded due to the fact that the infringement only produced its effects, without the defendant having acted there. ${ }^{21}$

After the CJEU's ruling in Coty Germany it remained unclear for some time whether for a Member State to qualify as a place where the act of infringement

\footnotetext{
18 CJEU, 5 June 2014, Case C-360/12, Coty Germany GmbH v. First Note Perfumes NV.

19 Id., para. 47 (referring to Art. 5(3) of Regulation (EC) No 2001/44 which preceded the BR I a).

20 Id., para. 57.

21 Id., para. 38. For a critical assessment of that decision, see Kur (2015) pp. 468-480.
} 
occurs it must be established that the alleged defendant physically acted in that territory. Support for that position could arguably be drawn from the CJEU's reference to the defendant having to engage in "active conduct" 22 within the territory concerned for there to have been an "act of infringement". That understanding would have rendered Art. 125(5) EUTMR and Art. 82(5) CDR largely moot, in particular where goods are offered and distributed through the internet.

Before the issue was clarified, the CJEU had an opportunity to specify its position concerning the determination of the law applicable to sanctions for infringement of unitary rights in case that the pertinent measures are not regulated in the EUTMR or the CDR. The issue had already been addressed in Gautzsch v. Duna ${ }^{23}$ however, as the Rome II Regulation had not been in force when the lawsuit was filed, Art. 8(2) Rome II was not addressed in the decision. The plaintiff in Gautzsch claimed rights in an unregistered Community design (UCD) that was allegedly infringed in several Member States. The German Federal Supreme Court (BGH) referred to the CJEU the question under which law (or laws) the plaintiff's claims for destruction, information and damages had to be decided. ${ }^{24}$ On the one hand, the BGH referred to arguments made in the literature that identifying a single point of attachment for the law to be applied was conducive to efficient enforcement ${ }^{25}$ but, on the other hand, the wording of Art. 89(1)(d) CDR was held to suggest that the national law of any individual Member State affected by the infringement must be applied (mosaic approach). ${ }^{26}$ The CJEU did not comment on those considerations, but only pointed out that the law applicable to "other sanctions" in the meaning of Art. 89(1)(d) as well as to matters not regulated in the CDR (Art. 88(2) CDR) is the law of the Member State where the court is situated, including its private international law. ${ }^{27}$

Questions remaining as to the interpretation of Art. 8(2) Rome II were answered in Nintendo $v$. BigBen. ${ }^{28}$ The plaintiff claimed infringement of its CD, jointly undertaken in several EU Member States by the defendants, a French-based mother company and its daughter established in Germany. Again the question arose as to the law applicable to ancillary sanctions such as damages, destruction, and publication of judgments. The CJEU noted that, as a general rule, the law applicable under Art. 8(2) Rome II is the law of the "country where the event giving rise to the damage occurs", and not, as in the general rule enshrined in Art. 4(1) Rome II, the

\footnotetext{
22 CJEU, Case C-360/12, Coty Germany, para. 34.

23 CJEU, 13 February 2014, Case C-479/12, Gautzsch v. Duna.

24 BGH, 16 August 2012, Case I ZR 74/10, Gartenpavillon. This was only one of a catalogue of six questions concerning a number of aspects regarding the conditions for protection of UCDs.

25 Id., para. 48.

26 Id., para. 49.

27 Case C-479/13, Gautzsch v. Duna, para. 55. Different from the CJEU, the Advocate General had taken a position in the matter, sharing the referring court's argument that a mosaic must be applied; see opinion by Advocate General Wathelet, 5 September 2013, para. 99 et seq.

28 CJEU, 27 September 2017, Joined Cases C-24/16 and C-25/16, Nintendo v. BigBen.

29 Id., para. 98.
} 
"country in which the damage occurs". ${ }^{29}$ Considering that in proceedings relating to intellectual property rights it is not uncommon for the same defendant to be accused of several infringing acts, several places could constitute the relevant connecting factor for determining the applicable law, ${ }^{30}$ resulting in a mosaic approach. That proposition is evaluated in the light of the factors guiding the interpretation of Art. 8(2) Rome II, which the CJEU identifies as legal certainty, foreseeability and the aim of striking a reasonable balance of interests. ${ }^{31}$ The CJEU then concludes that

[i]n the light of those objectives, where the same defendant is accused of various acts of infringement ... in various Member States, the correct approach for identifying the event giving rise to the damage is not to refer to each alleged act of infringement, but to make an overall assessment of that defendant's conduct in order to determine the place where the initial act of infringement at the origin of that conduct was committed or threatened. ${ }^{32}$

In cases like the one at issue, it is therefore possible to identify a single connecting factor linking to a single national law instead of applying a mosaic approach.

Nintendo achieved a welcome clarification insofar as the law applicable to ancillary sanctions in case of multi-Member-State infringement of unitary IP rights is concerned. However, the decision risked exacerbating the problems concerning the interpretation of Art. 125(5) EUTMR and Art. 82(5) CDR. If the words "act of infringement" were to be interpreted synonymously with the CJEU's reading of the same term appearing in Art. 8(2) Rome II, this would mean that proceedings on the basis of Art. 125(5) EUTMR and Art. 82(5) CDR could only be brought in the courts situated in the Member State where, according to an overall assessment, the "initial act of infringement" was committed. In the large majority of cases that place would coincide with the defendant's seat or establishment, if that exists in the EU; ${ }^{33}$ the provision would thereby become all but meaningless. Nevertheless, that interpretation was endorsed by the German Federal Supreme Court, ${ }^{34}$ which was so convinced of its position that the judges considered it needless to refer the issue to the CJEU. ${ }^{35}$ Fortunately, the Court of Appeal for England and Wales reacted soon thereafter $^{36}$ and requested the CJEU's opinion on Art. 125(5) EUTMR in a case concerning marketing of EUTM-infringing articles via a website operated from Spain to customers inter alia in the UK (AMS Neve v. Heritage Radio). ${ }^{37}$ The CJEU

\footnotetext{
30 Id., para. 99.

31 Id., para. 102.

32 Id., para. 103.

33 If the defendant is not domiciled and does not have a business establishment in the EU, the initial act of infringement may be located outside the EU, which makes the Nintendo formula inapplicable; see the text below.

34 BGH, 9 November 2017, Case I ZR 164/16, Parfummarken, (2018) IIC 485.

35 Id., paras. 51, 52. For a critical comment on that decision and in particular the BGH negating the necessity of a referral, see A. Kur, (2018) IIC 452, 464.

${ }^{36}$ AMS Neve Ltd \& Ors v. Heritage Audio SL \& Anor [2018] EWCA Civ 86, 1 February 2018 (Lord Justice Kitchin).

37 CJEU, 5 September 2019, Case C-172/18, AMS Neve v. Heritage Radio.
} 
set the matter straight. The judgment points out, first, that Art. 125(5) EUTMR (then: Art. 97(5) CTMR) is meant to provide an alternative to the venues listed in Art. 125(1)-(4), ${ }^{38}$ and that the interpretation must be guided (inter alia) by that aspect. The Court then refers to its decision in Coty Germany, and that the criterion for jurisdiction in (then) Art. 93(5) CTMR relates to "active conduct". ${ }^{39}$ As a basis for assessing whether such conduct was made by the defendant, the CJEU points to Art. 9 EUTMR which sets forth the conditions for infringement and a list of actions that fall within the exclusive right of the trade mark holder, including advertising and offering for sale products under the mark. If such acts occur by electronic means,

it is necessary ... to hold that those acts were committed in the territory where the consumers or traders to whom that advertising and those offers for sale are directed are located, notwithstanding the fact that the defendant is established elsewhere, that the server of the electronic network that he uses is located elsewhere, or even that the products that are the subject of such advertising and offers for sale are located elsewhere. ${ }^{40}$

Any other solution would make it easy for an infringer to evade the application of Art. 9 EUTMR, and it would undermine the efficiency of Art. 125(5) EUTMR and its predecessors to provide an alternative forum. ${ }^{41}$ Accordingly,

the expression "the act of infringement" must be understood as relating to acts, specified in Article 9, which the applicant claims to have been committed by the defendant ... and those acts must be held to have been "committed" in the territory where they can be classified as advertising or as offers for sale, namely where their commercial content has in fact been made accessible to the consumers and traders to whom it was directed. ${ }^{42}$

\subsection{Comment}

The language chosen by the CJEU in $A M S$ Neve is clear enough to disperse any doubts about the applicability of Art. 125(5) EUTMR where the right-holder seeks to enjoin and obtain redress against individual acts of infringement forming part of a larger operation conducted from a different Member State. It must be added, however, that the confusion about the role and interpretation of Art. 125(5) EUTMR is at least partly due to the CJEU's own unfortunate attempts to transpose the scheme developed in general tort law to the differently structured area of IP rights. ${ }^{43}$ In private international law pertaining to torts, it is an established feature to distinguish between the place where an event giving rise to damage occurs, and the

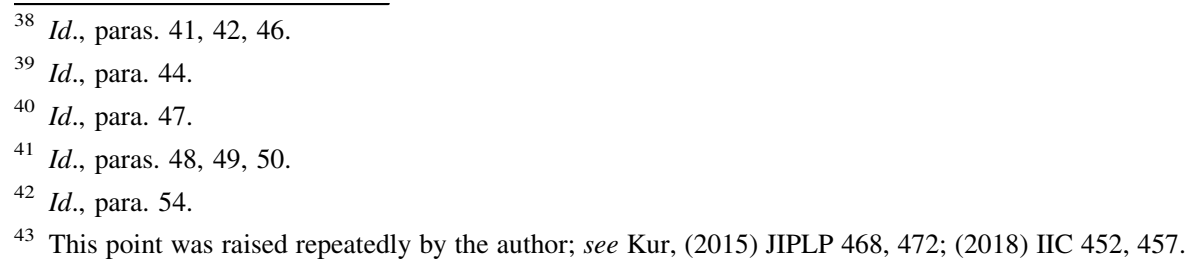


place where that damage takes effect. Due to the territoriality principle, that scheme cannot apply properly in the field of IP law. It is simply not possible for "damage" in the meaning of IP infringement to ensue in a country without an "event" in the meaning of an infringing act also being committed there; both necessarily coincide with regard to the territory where they occur. ${ }^{44}$ Of course, that does not exclude that an act of infringement committed in one particular Member State results from a central activity carried out in a different Member State (or possibly even outside the EU). This does not change the fact, however, that the dichotomy of "place of the harmful event" (locus delicti commissi) and "place of the harmful effect" (locus damni) established in private international law makes no sense regarding IP infringement. The relevant distinction rather applies between the place where events leading to further infringing acts were initiated and the place where individual acts prohibited under the relevant provision(s) of IP law were committed. None of those is a mere "locus damni"; the notion of "locus delicti commissi" fits both of them, albeit in different ways. Both varieties of the notion have a proper place in the arena where private international law interacts with IP law, depending on the circumstances of the case and the claims raised, as is shown in the following.

\subsection{Case Pending: $B M W$ v. Acacia}

\subsubsection{Background}

At the time of writing, a request for a preliminary decision is pending before the CJEU. $^{45}$ The underlying dispute arose between BMW and an Italian maker of wheel-caps, some of which reproduced a CD protected for BMW. The products were distributed in the entire EU, including in Germany. BMW raised an infringement claim before the District Court of Düsseldorf. The court assumed competence under Art. 82(5) CDR and granted the claim, inter alia ordering the defendant to render accounts so as to calculate damages. The defendant observed that Italian law - which he claimed was applicable to the sanctions not regulated in

\footnotetext{
44 This also applies to national rights. The CJEU's reference to the concept of locus damni as a criterion for allocating tort jurisdiction in case of infringement of national IP rights or claims based on unfair competition (CJEU, Case C-360/12, Coty Germany; supra, Sect. 1; see also CJEU, 19 April 2012, Case C-523/10, Wintersteiger v. Products 4U; 3 October 2013, Case C-170/12, Peter Pinckney v. Mediatech) is therefore likewise flawed. If, as in Pinckney, the plaintiff does not even contend that the defendant has committed an infringing act in the territory where the deciding court is situated, the claim must necessarily be rejected. Inviting the plaintiff to nevertheless file a claim in such a venue (as was done in Pinckney) runs counter to principles of sound administration of justice.

45 Pending Case C-421/20, BMW v. Acacia.

46 Court of Appeal (Oberlandesgericht - OLG) Düsseldorf, 31 August 2020, I-20 U 73/15.
} 
the CDR - does not provide for such measures. The Düsseldorf Court of Appeal thereupon referred the following questions to the CJEU: ${ }^{46}$

1. In proceedings for an infringement of Community designs, can the national court dealing with the infringement proceedings having international jurisdiction pursuant to Article 82(5) of the Community Designs Regulation apply the national law of the Member State in which the court dealing with the infringement proceedings is situated (lex fori) to subsequent claims in relation to the territory of its Member State?

2. If Question 1 is answered in the negative: Can the "initial place of infringement" for the purposes of the CJEU judgments in Cases C-24/16, C-25/16, Nintendo, regarding the determination of the law applicable to subsequent claims under Article 8(2) [Rome II] also lie in the Member State where the consumers to whom internet advertising is addressed are located and where goods infringing designs are put on the market within the meaning of Article 19 [CDR], in so far as only the offering and the putting on the market in that Member State are challenged, even if the internet offers on which the offering and the putting on the market are based were launched in another Member State?

The plaintiff in this dispute contends that Art. 8(2) Rome II is inapplicable because, for the reasons spelled out in Nintendo, the provision only relates to the situation that infringement claims pertain to several EU Member States. Against that, the referring court argues that application of German law "would contradict the objective of the Rome II Regulation to apply, for the purpose of harmonisation, the same law throughout the EU, irrespective of the venue". ${ }^{47}$ In addition, the referring court points out that, if German law were applied in this case, this would mean that a different law applies in the case that redress is claimed for the infringement in its entirety, "although the claims pertain to the same acts and the same damage". ${ }^{48}$ The court therefore endorses the opinion that Italian law applies as the law of the Member State where the infringement was initiated. In that context, the court doubts that the CJEU's decision in AMS Neve (where the CJEU acknowledged that an "act of infringement" is committed wherever conduct prohibited under Art. 9 EUTMR occurs) has in any way restricted or renounced what has been decided with regard to applicable law in Nintendo.

\footnotetext{
47 Id., para. 7 (author's translation).

48 Id., para. 7 (author's translation).
} 


\subsubsection{Analysis and Suggested Solution}

3.3.2.1 Lex Fori As pointed out above, rules concerning private international law in matters concerning a CD are set forth in Arts. 88 and 89 CDR. For matters not regulated in the CDR itself, Art. 88(2) refers to national law, including domestic private international law. While the matter was therefore left entirely to national jurisdiction in Gautzsch, ${ }^{49}$ this changed from the point in time when the Rome II Regulation entered into force. Since then, any reference in instruments of EU law to private international law in matters covered by the Rome II Regulation must be understood as a reference to the provisions set forth therein. ${ }^{50}$ The argument made by the plaintiff that Art. 8(2) Rome II is inapplicable would therefore only be valid if the dispute did not have any cross-border impact. ${ }^{51}$ However, such impact clearly exists here: not only is the defendant a company based in Italy, but the infringement concerns a unitary right that extends throughout the EU. Thus, even though as a result German law should apply in this case, taking the short cut of simply relying on lex fori is not a viable option. This is corroborated by Art. 88(3) CDR, which limits the application of lex fori to issues of procedural law.

3.3.2.2 Applicable Law as Determined Under Art. 8(2) Rome II The questions referred to the CJEU seem to suggest that a choice must be made between either applying lex fori or, if that should be denied, accepting that the point of attachment for the law applicable under Art. 8(2) Rome II must be determined according to the formula developed in Nintendo. However, that choice is too narrow. It omits the alternative that German law applies simply because it is the law of the Member State where the acts of infringement to which the claim pertains have been committed, without any need for invoking or re-interpreting the Nintendo formula.

Different from what the referring court suggests, ${ }^{52}$ that approach does not amount to a renunciation or restriction of what the CJEU said in Nintendo. On the contrary, the CJEU pointed out in Nintendo that each infringing act undertaken in the various Member States could, in principle, serve as a connecting factor for determining the applicable law. ${ }^{53}$ It was only declared in the decision, and was repeated in the operative part of it, that a different point of attachment must apply "where the same defendant is accused of various acts of infringement ... in various Member

\footnotetext{
49 Supra note 23 and accompanying text.

${ }^{50}$ CJEU, Joined Cases C-24/16 and 25/16, Nintendo v. BigBen, para. 93. This is not changed by the fact that, pursuant to Art. 27 Rome II, the Regulation "shall not prejudice the application of provisions of Community law which, in relation to particular matters, lay down conflict-of-law rules relating to noncontractual obligations", as - different from international jurisdiction - the EUTMR and the CDR do not contain specific rules on private international law except for referring to "national law" which has now been replaced by the Rome II Regulation.

51 See Recital 1 of the Rome II Regulation.

52 OLG Düsseldorf, 31 August 2020, I-20 U 73/15, para. 7.

53 CJEU, Joined Cases C-24/16 and 25/16, Nintendo v. BigBen, para. 99.
} 
States". ${ }^{54}$ The validity of the latter principle remains not in question. However, it does not determine the relevant point of attachment in cases that do not conform to the situation addressed in Nintendo.

This becomes particularly obvious in a situation where the defendant initiated the acts of infringement in a non-EU country. In that case, applying the law of that country is definitely excluded. ${ }^{55}$ Other points of attachment must be identified, either by relating to a (secondary) hub of activities in the EU or, where that does not exist, by referring to the law of the countries where individual acts of infringement are committed. As shown before (Sect. 3.2), the term "act of infringement" is broad enough to encompass all those alternatives. It is true that the CJEU insists that reference to the concept of "act of infringement" in Art. 8(2) Rome II must be given an "independent and uniform" meaning. ${ }^{56}$ However, that primarily means that the solution may not vary between Member States; it does not exclude that different points of attachment apply depending on the specifics of the dispute.

The CJEU has declared in Nintendo that the question of which of the notions comprised in the term "act of infringement" applies in a given context depends on an interpretation undertaken in the light of foreseeability and legal certainty, as well as on the aim to strike an appropriate balance between the interests involved. ${ }^{57}$ Applying those principles to the situation presented in Nintendo, the CJEU contended that taking a mosaic approach, in the sense that the law of all Member States involved in the infringement must be applied to the sanctions, would make determination of the substantive law rather unpredictable. ${ }^{58}$ One may have doubts whether that argument is completely convincing. It should normally be clear for the parties, in particular for the defendant, in which Member States the impugned business activities were carried out, so that the national laws applicable under a mosaic approach should generally not be too difficult to predict. However, the approach chosen in Nintendo is unquestionably superior to a mosaic approach in terms of procedural efficiency. Having to apply a number of different laws within the same proceedings would be cumbersome in terms of time and costs, thereby jeopardising the aim of efficient and secure protection against widespread infringement of unitary rights. From the viewpoint of efficiency and security, it is also important that infringements extending over several Member States are frequently initiated at the defendant's place of domicile, where litigation in such cases must be instigated pursuant to Art. 82(1) CDR (or, in case of EUTMs, Art. 125(1) EUTMR). The coincidence of the venue and the relevant point of attachment for the law applicable under Art. 8(2) Rome II makes it possible for the competent court to apply its own law, which is a substantial, though not necessarily decisive,

\footnotetext{
54 Id., para. 103 and No. 3 of the operative part; see also para. 90: "The referring court also raises the issue of the interpretation of the concept of 'country in which the act of infringement was committed' ... in circumstances such as those at issue in the main proceedings, where each defendant in the main proceedings is accused of several infringing acts committed in various EU Member States" (emphasis added).

55 For the reasons, see A. Kur, (2018) IIC 452, 463.

56 CJEU, Joined Cases C-24/16 and 25/16, Nintendo v. BigBen, para. 94.

57 Id., para. 102.

58 Id., para. 101.
} 
factor bolstering the expedience of proceedings and the legal certainty of judgments delivered on that basis.

The situation is completely different when litigation only concerns infringements occurring in one single Member State. Applying the law of the country where the individual act(s) of infringement occur does not pose any problem with regard to predictability, nor does it hamper procedural efficiency. Furthermore, in the large majority of claims brought before an infringement court whose competence is based on Art. 82(5) CDR (or Art. 125(5) EUTMR), the venue does not coincide with the Member State in which the infringement in its entirety has been initiated. If the point of attachment for the applicable law were nevertheless bound to relate to the latter activities, infringement courts would frequently have to apply a different law from the law of the Member States where the infringing acts to which the plaintiff's claims pertain are actually committed. This could lead to skewed results if the procedural context in which the relevant sanctions operate in a domestic context differs from that at the infringement venue. For instance, the aspect that under Italian law the holder of an IP right cannot request rendering of accounts ${ }^{59}$ may be compensated in the domestic context by the fact that Italian judges have wide discretion for estimation of damages, whereas in the context of German law, failure of accounts being rendered seriously jeopardises the computation of damages by the plaintiff and the court.

An analysis undertaken in the light of efficiency, legal certainty and a balance of interests therefore arrives at the conclusion that the Nintendo formula is inappropriate for defining the point of attachment in cases concerning infringement in one single Member State. It is preferable and more appropriate to apply the law of the Member State where the individual acts to which the claim pertains have been committed.

\subsubsection{Different Laws - Same Subject Matter?}

Concluding that it is possible and appropriate to identify two different points of attachment for the law applicable under Art. 8(2) Rome II does not yield a final answer to the question whether doing so might compromise the system established by the Regulation. Doubts in that regard could ensue if the approach results in different substantive laws being applied to the same subject matter. That risk is addressed by the referring court in BMW v. Acacia. ${ }^{60}$ The approach endorsed here is rejected inter alia with reference to the argument that different laws would apply, depending on whether the plaintiff chooses to claim redress for the infringement in its entirety or for individual acts of infringement committed in a single country. ${ }^{61}$ While that is true, it is not a sign of inconsistency. The diversity of laws applying to

\footnotetext{
59 As was noted above, this is what the defendant in the case pending before the CJEU contends and seeks to corroborate by producing a statement of legal opinion as to the contents of Italian law. It cannot be evaluated here whether the defendant's contention is actually correct or, if it is, whether failure of national law to provide for a duty of rendering accounts by an infringer to enable a correct calculation of damage claims is compatible with the Enforcement Directive (2004/48/EC).

60 Supra note 46.

${ }^{61}$ Id., para. 7.
} 
the sanctions are explained by the fact that the respective claims differ in their substance. Where claims concern the infringement in its entirety, the tort is completed in the Member State where the initial action is taken. In that scenario, acts occurring in other Member States are of relevance only insofar as they relate to the dimensions of the infringement; they concern quantity, and not the substance of the claim as such. This is different from the situation that acts of infringement in individual Member States are singled out and are litigated separately before the courts in the Member State where those infringements occur. The substance of claims raised is also different when the right-holder chooses to bring a number of proceedings in individual Member States, each one concerning specific acts of infringement occurring there. In that case as well, the law applying to the sanctions is different in consequence of the fact that the claims only relate to the specific acts committed in the respective Member States.

In accordance with that view the CJEU has repeatedly emphasised that infringement claims concerning the same right being infringed in different territories do not concern the same subject matter. ${ }^{62}$ In that context the CJEU also contended that "the courts of the various Member States before which actions are brought in such circumstances cannot deliver 'contradictory judgments', within the meaning of recital 17 of Regulation No 207/2009, since the actions that the applicant has brought relate to distinct territories". 63

While that statement can be endorsed insofar as ancillary sanctions for specific acts of infringement committed in the different territories are concerned, it is not convincing where divergences relate to the constituent elements of the infringement as such. For instance, if in a case concerning CD infringement, different national courts arrive at diverging conclusions regarding the question of the overall impression produced on an informed user by the allegedly infringing design, it can hardly be said that the decisions are not contradictory. ${ }^{64}$ Mere diversity of territories does not change the fact that the subject-matter in both cases is the same. The situation is the same in principle in regard to trade mark conflicts, for instance concerning the question whether the sign used by the alleged infringer and the goods or services in relation to which it is used are sufficiently similar to give rise to a

\footnotetext{
${ }^{62}$ CJEU, Joined Cases C-24/16 and C-25/16, Nintendo v. BigBen, para. 46; Case C-172/18, AMS Neve, para. 42. Inter alia this means that the principle of lis pendens (Art. 29 BR I a) does not apply insofar as litigation between the same parties over the same or parallel rights pertains to different territories (CJEU, 19 October 2017, Case C-231/16, Merck, para. 42). Vice versa it follows that where an action concerning EU-wide infringement of the same right by the same defendant is filed after proceedings for specific acts of infringement were raised in a single Member State, the court second seized must stay the case or, if the competence of the court first seized has already been established, decline jurisdiction insofar as the alleged infringements relate to the same territory.

63 CJEU, Case C-172/18, AMS Neve, para. 42. Recital 17 of the Preamble to Regulation No 2009/207 (now: Recital 33 of the Preamble to the EUTMR). "Contradictory judgments should be avoided in actions which involve the same acts and the same parties and which are brought on the basis of a Community trade mark and parallel national trade marks". While this only addresses parallel national rights and EUTMs, the same must apply even more concerning claims filed for infringement of unitary rights in their entirety and claims pertaining to specific acts of infringement in individual Member States.

64 The Preamble to the CDR does not contain a similar recital as that quoted by the CJEU in AMS Neve (supra note 63). Nevertheless, it is assumed that the CJEU's statement that court decisions pertaining to the same infringement occurring in different territories cannot be contradictory also applies here.
} 
likelihood of confusion. ${ }^{65}$ The issue is not addressed in the CDR or EUTMR, ${ }^{66}$ leaving it without remedy. ${ }^{67}$ This is another deficiency resulting from the fragmented nature of the system; however, it concerns a general issue of lacking coordination of court decisions and does not affect the validity of the approach espoused towards the interpretation of Art. 8(2) Rome II.

\section{Concluding Remarks}

At the beginning of this essay reference was made to the yet-to-become-operational unified judicial system forming part of the so-called patent package. For all the flaws potentially troubling the system, ${ }^{68}$ it provides relatively clear-cut solutions for the issues addressed above. ${ }^{69}$ Jurisdiction of courts participating in the system ${ }^{70}$ and the applicable law $^{71}$ are regulated comprehensively in the UPCA. Courts of first instance established at the national or regional level as well as the central divisions form part of one single judiciary with a common appeal court, instead of remaining part of their own national court hierarchy. Furthermore, and very importantly, the UPCA contains its own catalogue of measures to be taken by the courts, including sanctions for infringement, ${ }^{72}$ which provides a de facto uniform legal basis for the courts to proceed on. The questions arising in Nintendo and the pending case of $B M W v$. Acacia would therefore be moot.

There does not seem to be a realistic prospect soon for a genuinely unitary judicial system to be established for EUTMs and CDs. However, at least the lastmentioned aspect in the UPCA, unification of sanctions, does not seem to be completely out of reach for other unitary rights as well. Doing so would considerably ease the frictions between the aspired aim of granting uniform

\footnotetext{
65 It is true that in trade mark law, the perception by the relevant public which serves as a yardstick for assessing likelihood of confusion is impacted by a number of factors that can change between Member States (and/or linguistic regions). This may explain differences between diverging judgments more easily than in design law.

66 This is different from decisions concerning the validity of trade marks or industrial designs; in that regard, prior decisions by courts and/or the EUIPO bind all other potential actors. See Arts. 86, 91 CDR and Arts. 128, 134 EUTMR.

67 The same applies regarding differences in the results of decisions rendered within the framework of registration or cancellation proceedings at the EUIPO leading to decisions by the General Court on the one hand, and decisions in the same conflict by EU trade mark courts on the other. This happened for instance in the conflict between the (then) CTM application "ZIRH" and the trade mark "SIR" protected in Germany for identical and similar goods. While a likelihood of confusion was denied in opposition proceedings before the EUIPO (then: OHIM), with the decision being confirmed by the General Court (3 March 2004, T-355/02, Mülhens v. OHIM, ECLI:EU:T:2004:62) and the CJEU (13 March 2006, C-206/ 04 P, Mülhens v. OHIM, EU:C:2006:194), in the parallel infringement proceedings before the district court, the junior trade mark was found to be infringing, Hamburg District Court (Landgericht $-L G$ ), 6 May 2004, 315 O 158/03. See von Mühlendahl (2005), pp. 503-513.

68 Hilty et al. (2012)

69 See e.g. Ullrich (2015) pp. 1-9.

70 Art. 31 et seq. UPCA.

71 Art. 24 UPCA.

72 Art. 56 et seq.
} 
protection and a still somewhat fractured reality when it comes to the enforcement level.

Funding Open Access funding enabled and organized by Projekt DEAL.

Open Access This article is licensed under a Creative Commons Attribution 4.0 International License, which permits use, sharing, adaptation, distribution and reproduction in any medium or format, as long as you give appropriate credit to the original author(s) and the source, provide a link to the Creative Commons licence, and indicate if changes were made. The images or other third party material in this article are included in the article's Creative Commons licence, unless indicated otherwise in a credit line to the material. If material is not included in the article's Creative Commons licence and your intended use is not permitted by statutory regulation or exceeds the permitted use, you will need to obtain permission directly from the copyright holder. To view a copy of this licence, visit http:// creativecommons.org/licenses/by/4.0/.

\section{References}

Gandía Sellens M (2018) The viability of the unitary patent package after the UK's ratification of the Agreement on a Unified Patent Court. IIC 136-152

Hilty RM, Jaeger T, Lamping M, Ullrich H (2012) The unitary patent package: twelve reasons for concern. Max Planck Institute for Intellectual Property \& Competition Law Research Paper No. 12-12. available at SSRN: https://ssrn.com/abstract=2169254 or http://dx.doi.org/10.2139/ssrn. 2169254

Jaeger T (2017) Reset and go: the unitary patent system post-Brexit. IIC 254-285

Kur A (2015) Enforcement of unitary intellectual property rights: international jurisdiction and applicable law. JIPLP 468-480

Pagenberg J (1987) Protection of get-up and character merchandising under German law. IIC 457

Pagenberg J (2000) The First Instance European Patent Court - a tribunal without judges and attorneys? IIC $481-491$

Pagenberg J (2007) Another year of debates on patent jurisdiction in Europe and no end in sight? IIC $805-825$

Pagenberg J (2009) Die Zukunft nationaler Patentgerichte im System einer künftigen europäischen Gerichtsbarkeit. GRUR 314-318

Pagenberg J (2010) Neue Überlegungen zur europäischen Patentgerichtsbarkeit - ist Deutschland noch zu retten? GRUR Int 195-198

Pagenberg J (2010) The ECJ on the Draft Agreement for a European Community Patent Court - Hearing of May 18, 2010. IIC 695-707

Pagenberg J (2012) Die EU-Patentrechtsreform - zurück auf Los? GRUR 582-589

Tilmann W (2020) The UPC without the UK: consequences and alternatives. IIC 847-851

Ullrich H (2015) The European patent and its courts: an uncertain prospect and an unfinished agenda. IIC $1-9$

von Mühlendahl A (2005) Rechtsstreitigkeiten über Gemeinschaftsmarken: Eintragungsverfahren und Verletzungsverfahren dargestellt am Fall SIR/ZIRH, in: Kur A, Luginbühl S, Waage E (eds) ...und sie bewegt sich doch! Patent law on the move, essays in honour of Dieter Stauder and Gert Kolle, pp 503-513

Publisher's Note Springer Nature remains neutral with regard to jurisdictional claims in published maps and institutional affiliations. 